\title{
Preliminary evaluation for quality of dimension lumber in four common softwoods in Mongolia
}

\author{
Murzabyek Sarkhad ${ }^{1,2,3}$, Futoshi Ishiguri ${ }^{1 *} \mathbb{B}$, Ikumi Nezu1', Bayasaa Tumenjargal 1,2,3, Yusuke Takahashi', \\ Bayartsetseg Baasan ${ }^{3}$, Ganbaatar Chultem ${ }^{4}$, Jyunichi Ohshima ${ }^{1}$ and Shinso Yokota ${ }^{1}$
}

\begin{abstract}
The quality of dimension lumber ( 2 by 4 lumber) was preliminarily investigated in four common Mongolian softwoods: Pinus sylvestris L., Pinus sibirica Du Tour, Picea obovata Ledeb., and Larix sibirica Ledeb. to produce high quality dimension lumber for structural use. In total 61, 39, 67, and 37 pieces of lumber were prepared for Pinus sylvestris, Pinus sibirica, Picea obovata, and L. sibirica, respectively. The lumber was visually graded and then tested in static bending to obtain the $5 \%$ lower tolerance limits at $75 \%$ confidence level $\left(f_{0.05}\right)$ of the modulus of elasticity (MOE) and the modulus of rupture (MOR). In addition, the effects of sawing patterns on bending properties were also analyzed. The $f_{0.05}$ of the MOE and MOR were 4.75 GPa and 15.6 MPa, 3.39 GPa and 11.0 MPa, 3.78 GPa and 11.7 MPa, and $6.07 \mathrm{GPa}$ and $22.3 \mathrm{MPa}$ for Pinus sylvestris, Pinus sibirica, Picea obovata, and L. sibirica, respectively. These results suggested that with a few exceptions, characteristic values of MOR in the four common Mongolian softwoods resembled those in similar commercial species already used. In visual grading, over $80 \%$ of total lumber was assigned to select structural and No. 1 grades in Pinus sylvestris and Pinus sibirica, whereas approximately 40\% of total lumber in L. sibirica was No. 3 and out of grades. Sawing patterns affected bending properties in Pinus sylvestris and L. sibirica, but did not affect Pinus sibirica and Picea obovata. Dynamic Young's modulus was significantly correlated with bending properties of dimension lumber for the four species. Based on the results, it was concluded that dimension lumber for structural use can be produced from the four common Mongolian softwoods.
\end{abstract}

Keywords: Pinus sylvestris, Pinus sibirica, Picea obovata, Larix sibirica, Modulus of elasticity, Modulus of rupture, 5\% tolerance limit, Visual grading, Sawing pattern

\section{Introduction}

In Mongolia, coniferous tree species occupy over $70 \%$ in total forest area of 11.5 million hectares [1]. The amounts of $\log$ production were around $162,000 \mathrm{~m}^{3}$ from the coniferous forest at 2018 [2]. For approximately $70 \%$ of total forests, Larix sibirica Ledeb. $62.5 \%$, and the other species, including Pinus sylvestris L., Pinus sibirica Du Tour, and Picea obovata Ledeb., cover 9.8\% [1]. Thus, wood from these four species are considered as

\footnotetext{
${ }^{*}$ Correspondence: ishiguri@cc.utsunomiya-u.ac.jp

${ }^{1}$ School of Agriculture, Utsunomiya University, Utsunomiya 321-8505, Japan

Full list of author information is available at the end of the article
}

common softwoods for production of structural lumber in Mongolia.

Mechanical properties of structural lumber, such as dimension lumber, have been investigated for softwood species by many researchers [3-13]. In terms of mechanical properties, the $5 \%$ lower tolerance limit with a $75 \%$ confidence level $\left(f_{0.05}\right)$ in modulus of elasticity (MOE) and modulus of rupture (MOR) is important information for utilization of wood as structural material [14-17]. Dahlen et al. [16] reported that the $f_{0.05}$ values for Southern pine (Pinus spp.) were 5.8 to $8.2 \mathrm{GPa}$ and 13.0 to 23.0 $\mathrm{MPa}$ for MOE and MOR, respectively, in dimension lumber (No. 2 grade in visual grading) for 2 by 6,2 by 8 ,
SpringerOpen

(c) The Author(s) 2020. This article is licensed under a Creative Commons Attribution 4.0 International License, which permits use, sharing, adaptation, distribution and reproduction in any medium or format, as long as you give appropriate credit to the original author(s) and the source, provide a link to the Creative Commons licence, and indicate if changes were made. The images or other third party material in this article are included in the article's Creative Commons licence, unless indicated otherwise in a credit line to the material. If material is not included in the article's Creative Commons licence and your intended use is not permitted by statutory regulation or exceeds the permitted use, you will need to obtain permission directly from the copyright holder. To view a copy of this licence, visit http://creativeco mmons.org/licenses/by/4.0/. 
2 by 10 , and 2 by 12 cross sections. Recently, Tumenjargal et al. [13] reported that $f_{0.05}$ values of MOE and MOR in 2 by $4(38 \times 89 \mathrm{~mm})$ lumber of $L$. sibirica grown in Mongolia were $5.70 \mathrm{GPa}$ and $15.1 \mathrm{MPa}$, respectively. However, available information on $f_{0.05}$ for the MOE and MOR of dimension lumber for structural use remain limited for common softwoods in Mongolia.

Visual grading is one of the grading methods for lumber $[8,12,14,15,18-22]$. Erikson et al. [19] reported that the highest MOE and MOR values in 2 by 4 lumber of Pinus contorta Douglas ex Loudon were recorded in select structural (SS) grade, whereas lumber of No. 3 grade demonstrated the lowest MOE and MOR values. Similar results were obtained in 2 by $4(40 \times 90 \mathrm{~mm})$ lumber for Larix gmelinii (Rupr.) Kuzen.: the mean MOR value at $15 \%$ moisture content was $65.1 \mathrm{MPa}$ for SS, and the value was higher than those of other visual grades [22]. These results suggest that high bending properties can be obtained in lumber classified into higher visual grading classes. On the other hand, Tumenjargal et al. [13] reported that no significant differences in either the MOE or MOR of 2 by $4(38 \times 89 \mathrm{~mm})$ lumber in L. sibirica were found between SS, No. 1, No. 2, and No. 3 grade lumber, whereas the MOE and MOR in out of grade lumber showed notably lower values. Thus, further research is needed to clarify the relationship between visual grading results and bending properties of dimension lumber in each softwood species.

Effects of sawing pattern on mechanical properties of softwood lumber have been investigated for efficient lumber production [12, 13, 16, 23, 24]. In general, lower mechanical properties and instability of structural lumber are caused by the presence of juvenile wood with high microfibril angle [11, 16, 23]. In Pinus taeda L., significantly lower MOE and MOR were found in 2 by 4 lumber with pith rather than that without pith, due to the large percentage of juvenile wood contained in lumber with pith [24]. Thus, considering the sawing patterns in relation to the presence of juvenile wood is important for producing lumber with high mechanical properties.
To produce high quality dimension lumber for structural use in Mongolia, the lumber quality of four common softwoods, L. sibirica, Pinus sylvestris, Pinus sibirica, and Picea obovata, was preliminarily investigated in this study. Based on the results, the effects of visual grading and sawing patterns were evaluated in terms of the lumber's mechanical properties. In addition, $f_{0.05}$ of MOR in each species was compared to characteristic values of MOR $\left(F_{\mathrm{b}}\right)$ in Japanese Agricultural Standard (JAS) for structural lumber and finger jointed structural lumber for wood frame construction [25]. Furthermore, correlations among the different markers of lumber quality in each species were discussed. This is the first report on the evaluation of quality of dimension lumber in four common softwoods naturally grown in Mongolia, except for L. sibirica $[12,13]$.

\section{Materials and methods Materials}

The following four Mongolian common softwoods were used in the present study: Pinus sylvestris L., Pinus sibirica Du Tour, Picea obovata Ledeb., and Larix sibirica Ledeb. These trees were obtained from natural forests in Selenge, Mongolia $\left(48^{\circ} 49^{\prime} \mathrm{N}, 106^{\circ} 53^{\prime} \mathrm{E}\right.$ and $48^{\circ} 41^{\prime} \mathrm{N}$, $106^{\circ} 38^{\prime} \mathrm{E}$ ). In total, 20 trees (five trees in each species) were harvested. They had 20 to $30 \mathrm{~cm}$ of stem diameter at $1.3 \mathrm{~m}$ above the ground, with good stem shape without any severe damage. The stem diameter of trees in each species was similar to mean stem diameter in each species in each natural forest. Table 1 shows the number of annual rings, the stem diameter $1.3 \mathrm{~m}$ above the ground, and the tree height of the sampled trees. Annual ring numbers were 72, 62, 60, and 50 for Pinus sylvestris, Pinus sibirica, Picea obovata, and L. sibirica, respectively, suggesting that the age of the sample trees ranged from approximately $50-70$ years. Logs ca. $2 \mathrm{~m}$ in length were collected $1.3 \mathrm{~m}$ above the ground to the tree top until the top diameter of the log was less than $14 \mathrm{~cm}$. In all, 27, 16, 22, and 21 logs for Pinus sylvestris, Pinus sibirica, Picea obovata, and L. sibirica were collected, respectively.

Table 1 Number of annual rings, stem diameter, and tree height of sample trees

\begin{tabular}{|c|c|c|c|c|c|c|c|}
\hline \multirow[t]{2}{*}{ Species } & \multirow[t]{2}{*}{$n$} & \multicolumn{2}{|l|}{ NAR } & \multicolumn{2}{|c|}{$\mathrm{D}(\mathrm{cm})$} & \multicolumn{2}{|c|}{$\mathrm{TH}(\mathrm{m})$} \\
\hline & & Mean & SD & Mean & SD & Mean & SD \\
\hline Pinus sylvestris & 5 & 72 & 3 & 27.1 & 2.2 & 16.2 & 2.2 \\
\hline Pinus sibirica & 5 & 62 & 4 & 26.5 & 1.3 & 11.9 & 1.5 \\
\hline Picea obovata & 5 & 60 & 6 & 27.9 & 2.2 & 14.3 & 2.3 \\
\hline L. sibirica & 5 & 50 & 9 & 25.6 & 1.6 & 15.3 & 1.3 \\
\hline
\end{tabular}

$n$, number of trees; NAR, number of annual rings at $1.3 \mathrm{~m}$ above the ground; $\mathrm{D}$, stem diameter at $1.3 \mathrm{~m}$ above the ground; TH, tree height; SD, standard deviation 


\section{Lumber production}

Figure 1 shows lumber production procedures. Approximately $2 \mathrm{~m}$-length logs were sawn into lumber with cross section $(50 \times 100 \mathrm{~mm})$, maximizing the yield of lumber as much as possible. Sawing patterns were recorded for each $\log$. In all, 61, 39, 67, and 37 pieces of lumber were obtained for Pinus sylvestris, Pinus sibirica, Picea obovata, and L. sibirica, respectively. After sawing, the lumber was air-dried in a laboratory at ambient conditions in Ulaanbaatar, Mongolia from September 2018 to September 2019. During air drying, monthly minimum, maximum, and mean temperature and relative outdoor humidity in Ulaanbaatar were-20.3 ${ }^{\circ} \mathrm{C}$ (December 2018), $19.3{ }^{\circ} \mathrm{C}$ (July 2019), and $1.6{ }^{\circ} \mathrm{C}$, and $35 \%$ (May 2019), $67 \%$ (August 2019), and 49\%, respectively. After air-drying, the lumber was planed into $38 \times 89 \mathrm{~mm}$ cross sections, and then the lumber length was cut to $1820 \mathrm{~mm}$ using a cross cut saw.

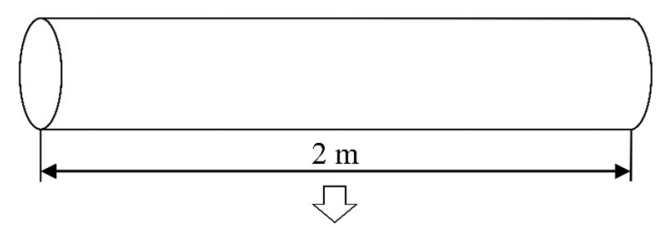

Four types of sawing patterns $(50 \times 100 \mathrm{~mm}$ cross section)
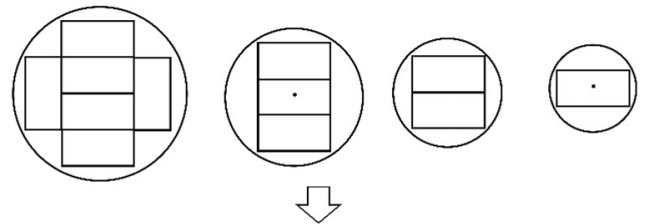

Total 61, 39, 67 and 37 pieces of lumber were obtained from 86 logs from Pinus sylvestris, Pinis sibirica, Picea obovata, and $L$. sibirica, respectively.

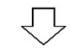

Air-drying<smiles>[C]1CC[Te]1</smiles>

Planing ( $38 \times 89 \mathrm{~mm}$ in cross section)

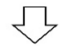

Lumber was classified three types.

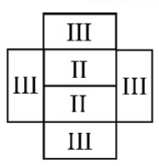

$$
\begin{array}{|c|}
\hline \text { III } \\
\hline \text { I } \\
\hline \text { III } \\
\hline
\end{array}
$$
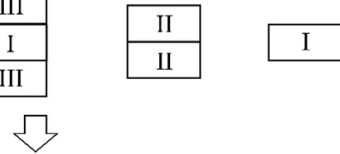

Visual grading

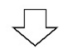

Static bending test

Fig. 1 Illustration of the experimental procedures. I, lumber including pith at almost-center position in cross-section; II, lumber obtained near the pith (sometimes including pith on the surface area of the lumber); III, lumber obtained from outer part of the logs (without pith)
To evaluate the effect of sawing patterns on lumber quality, the lumber was categorized into three types: lumber including pith at almost the center position in the cross section (I), lumber obtained near the pith (sometimes including pith on the surface area of the lumber) (II), and lumber obtained from the outer part of the log (without pith) (III) (Fig. 1).

\section{Visual grading of lumber}

Each lumber piece was graded according to JAS for structural lumber and finger jointed structural lumber for wood frame construction [25]. For grading, the typical visual sorting criteria, such as annual ring width, knot size, existence and size of holes, slope of grain, deformation (bow, crook, and twist), wane, and crack were measured on surfaces of all lumber as described in JAS [25]. Bow and crook were measured as the proportion of maximum deflection to the length of lumber. To measure twist, the lumber was set on the flat surface of a steel plate. After fixing three edges of lumber, distance was measured between the remaining one edge and the flat surface. The twist of the lumber was also evaluated as the angle calculated of the arcsine of the ratio of the lumber's measured distance to width. Based on the results, lumber was graded according to the following five visual grades: SS, No. 1, No. 2, No. 3, and out of grade.

\section{Dynamic Young's modulus}

The dynamic Young's modulus of the lumber was measured after visual grading using vibrational analysis [26]. The natural frequency of longitudinal vibration due to sound emitted by hitting the cross-section of lumber with a hammer was measured using a handheld fast Fourier transform analyzer (AD-3527, A\&D), with an accelerometer (PV-85, RION) set on the other cross end of each lumber. The dynamic Young's modulus of the lumber was calculated using the same methods described in Tumenjargal et al. [12].

\section{Static bending test}

Four-point static bending tests were conducted using a material testing machine (WDW-20E, Jinan Kason Testing Equipment) according to the methods described in Japan Housing and Wood Technology Center [27]. Crosshead speed, whole span, and distance between load points were $14 \mathrm{~mm} / \mathrm{min}, 1602 \mathrm{~mm}$, and $534 \mathrm{~mm}$, respectively. The load and deflection were measured by a load cell (LC-5TV, Kyowa) and a displacement transductor (DTH-A-100, Kyowa), respectively. After bending tests, static bending properties, MOE, and MOR were calculated by the following equations: 


$$
\begin{aligned}
& \operatorname{MOE}(\mathrm{GPa})=\frac{\Delta P\left(l-l^{\prime}\right)\left[3 l^{2}-\left(l-l^{\prime}\right)^{2}\right]}{8 \Delta y b h^{3}} \\
& \operatorname{MOR}(\mathrm{MPa})=\frac{3 P_{\max }\left(l-l^{\prime}\right)}{2 b h^{2}}
\end{aligned}
$$

where $\Delta P(\mathrm{~N})$ is difference of load between 10 and $40 \%$ values of maximum load $\left(P_{\max }\right), \Delta y$ is the difference in deflection corresponding to $\Delta P, l(\mathrm{~mm})$ is the span, $l^{\prime}$ $(\mathrm{mm})$ is the difference between load points, $b(\mathrm{~mm})$ is the width of the specimen, and $h(\mathrm{~mm})$ is the height of specimen.

After static bending tests, $2.5 \mathrm{~cm}$-thickness (longitudinal direction) small-clear specimens without defects were collected from each lumber to measure the annual ring width, moisture content at testing, and air-dry density at testing. The moisture content of lumber was measured using the oven-dry method. Results revealed that mean and standard deviation of moisture content were $11.7 \pm 0.4 \%$ for all pieces of lumber. Thus, MOE and MOR values were adjusted to those at $15 \%$ moisture content using the following formula described in Japan Housing and Wood Technology Center [27]:

$$
P_{2}=P_{1}(\alpha-\beta 15) /(\alpha-\beta M),
$$

where $P_{2}$ is the MOE or MOR value at a moisture content of $15 \%, P_{1}$ is the MOE or MOR value at testing, $M$ is the moisture content at testing, $\alpha$ is 1.44 and 1.75 for MOE and MOR, respectively, and $\beta$ is 0.0200 and 0.0333 for MOE and MOR, respectively.

\section{Data analysis}

Data analyses were conducted using Excel 2016 (Microsoft) and R software [28]. The MOE and MOR values for the $f_{0.05}$ were calculated using the following formula [17, 27]:

$$
f_{0.05}=\mu-K \sigma,
$$

where $\mu$ is the mean value, $K$ is a coefficient depending on the sample size (The $K$ values for Pinus sylvestris, Pinus sibirica, Picea obovata, and L. sibirica were 1.7932 $(n=61), 1.8365(n=39), 1.7856(n=67)$, and 1.8425 $(n=37)$, respectively), and $\sigma$ is the standard deviation. When the data was not fitted to normal distribution by Shapiro-Wilk test $(p<0.05), \mu$ and $\sigma$ were obtained by equivalent transformation from logarithmic normal distribution to normal distribution.

To evaluate the effects of visual grading on bending properties, data on MOE and MOR were again classified into three groups: (1) SS and No. 1, (2) No. 2 and No. 3, and (3) out of grade. Significant differences among visual grading classes and wood type (I, II, and III) were detected using the Tukey-HSD test at a 5\% significance level. The relationships between the measured lumber properties were determined using Pearson's correlation analysis.

\section{Results and discussion} Lumber properties and characteristic values

Table 2 shows statistical values of lumber properties in each species. The maximum mean ring width for a piece of lumber permitted by the JAS for structural lumber is $6 \mathrm{~mm}$ [25]. In the present study, maximum values of annual ring width in each species were approximately $3.5 \mathrm{~mm}$, indicating that annual lumber ring width from the four species naturally grown in Mongolia was not a downgrading factor in visual grading. The smallest mean values of crook and bow were found in Pinus sylvestris. In addition, the highest maximum values were recorded for crook $(0.49 \%)$ and bow (0.36\%) in Pinus sibirica. Mean values of twist were higher in Picea obovata (2.4 degree) and L. sibirica (3.5 degree) than in the other species. These results indicated that among the four species, crook and bow were severe in Pinus sibirica, and twist was severe in L. sibirica, followed by Picea obovata. Airdry density values were $0.44,0.43,0.39$, and $0.59 \mathrm{~g} / \mathrm{cm}^{3}$ for Pinus sylvestris, Pinus sibirica, Picea obovata, and L. sibirica, respectively. Although the highest value was recorded in $L$. sibirica, it demonstrated a large coefficient of variation value (12\%) compared to the other three species (5\% to 7\%). The highest dynamic Young's modulus of lumber was found in L. sibirica, followed by Pinus sylvestris, Picea obovata, and Pinus sibirica. The same trends were also found for MOE and MOR. Figure 2 shows frequency distribution of MOE and MOR in each species. The results of the Shapiro-Wilk test revealed that all distributions, except for MOR in $L$. sibirica, fitted to normal distribution. The distribution pattern in the MOR of $L$. sibirica fitted to logarithmic normal distribution. Among the tested species, $L$. sibirica demonstrated the highest $f_{0.05}$ for MOE (6.07 GPa) and MOR (22.3 MPa), whereas the lowest values were obtained in Pinus sibirica (3.39 GPa and 11.0 MPa, respectively). Based on the results, the lumber from the four species tested in the current study can be characterized as follows: (1) Lumber from Pinus sylvestris displayed low warp and moderate mechanical properties; (2) lumber from Pinus sibirica and Picea obovata displayed low mechanical properties and dimensional stability; and (3) lumber from L. sibirica demonstrated the highest bending properties but also higher twist.

Table 3 shows $F_{\mathrm{b}}$ for 2 by 4 lumber in softwood species groups [25] that are similar to the four species used in the present study and the quantity of lumber in each grade. In Pinus sylvestris, over $90 \%$ of total lumber were SS 
Table 2 Statistical values of lumber properties

\begin{tabular}{|c|c|c|c|c|}
\hline Property & Pinus sylvestris $(n=61)$ & Pinus sibirica $(n=39)$ & Picea obovata $(n=67)$ & L. sibirica $(n=37)$ \\
\hline \multirow[t]{2}{*}{ ARW (mm) } & $1.6 \pm 0.5$ & $2.2 \pm 0.5$ & $2.5 \pm 0.6$ & $2.4 \pm 0.6$ \\
\hline & $(1.0-3.4)$ & $(1.4-3.3)$ & $(0.2-3.5)$ & $(1.0-3.6)$ \\
\hline \multirow[t]{2}{*}{ Crook (\%) } & $0.06 \pm 0.04$ & $0.10 \pm 0.09$ & $0.08 \pm 0.06$ & $0.08 \pm 0.06$ \\
\hline & $(0.00-0.16)$ & $(0.00-0.49)$ & $(0.00-0.27)$ & $(0.00-0.27)$ \\
\hline \multirow[t]{2}{*}{ Bow (\%) } & $0.03 \pm 0.03$ & $0.05 \pm 0.07$ & $0.06 \pm 0.06$ & $0.07 \pm 0.07$ \\
\hline & $(0.00-0.16)$ & $(0.00-0.36)$ & $(0.00-0.30)$ & $(0.00-0.27)$ \\
\hline \multirow[t]{2}{*}{ Twist (degree) } & $0.5 \pm 0.0$ & $0.3 \pm 0.7$ & $2.4 \pm 2.7$ & $3.5 \pm 4.5$ \\
\hline & $(0.0-2.2)$ & $(0.0-3.3)$ & $(0.0-11.1)$ & $(0.0-17.7)$ \\
\hline \multirow[t]{2}{*}{$A D\left(\mathrm{~g} / \mathrm{cm}^{3}\right)$} & $0.44 \pm 0.03$ & $0.43 \pm 0.03$ & $0.39 \pm 0.02$ & $0.59 \pm 0.07$ \\
\hline & $(0.40-0.50)$ & $(0.38-0.50)$ & $(0.36-0.48)$ & $(0.45-0.75)$ \\
\hline \multirow[t]{2}{*}{ DMOE (GPa) } & $10.55 \pm 1.57$ & $8.16 \pm 1.57$ & $8.55 \pm 1.17$ & $13.11 \pm 2.21$ \\
\hline & $(6.22-13.95)$ & $(5.59-12.04)$ & $(4.54-11.80)$ & $(9.13-18.71)$ \\
\hline \multirow[t]{2}{*}{ MOE (GPa) } & $6.56 \pm 1.01$ & $5.10 \pm 0.93$ & $5.32 \pm 0.86$ & $8.52 \pm 1.33$ \\
\hline & $(3.47-8.41)$ & $(3.44-6.86)$ & $(3.22-7.30)$ & $(6.48-11.95)$ \\
\hline \multirow[t]{2}{*}{ MOR (MPa) } & $38.6 \pm 12.8$ & $25.0 \pm 7.6$ & $26.7 \pm 8.4$ & $44.5 \pm 16.4$ \\
\hline & $(14.4-68.4)$ & $(11.2-40.5)$ & $(9.7-49.1)$ & $(18.0-95.2)$ \\
\hline $\mathrm{MOE} f_{0.05}(\mathrm{GPa})$ & 4.75 & 3.39 & 3.78 & 6.07 \\
\hline $\mathrm{MOR} f_{0.05}(\mathrm{MPa})$ & 15.6 & 11.0 & 11.7 & 22.3 \\
\hline
\end{tabular}

$n$, number of lumber; ARW, annual ring width; AD, air-dry density at testing; DMOE, dynamic Young's modulus; MOE and MOR, modulus of elasticity and modulus of rupture adjusted to the values at $15 \%$ moisture content by the methods described in Japan Housing and Wood Technology Center [27]; $f_{0.05}, 5 \%$ lower tolerance limit with $75 \%$ confidence level. The value indicates mean \pm standard deviation. The values in parentheses indicate minimum and maximum values. Mean and standard deviation of moisture content was $11.7 \pm 0.4 \%$ for all pieces of lumber

and No. 1 grades in the Spruce-Pine-Fir (S-P-F) species group. Similar results were obtained in Pinus sibirica and L. sibirica. Approximately $85 \%$ of total lumber for Pinus sibirica belonged to SS and No. 1 grades in the W Cedar species group, which includes similar species, Pinus koraiensis Siebold \& Zucc. Furthermore, over $90 \%$ of total lumber of $L$. sibirica classified into SS and No. 1 grades in D. fir-L, Hem-Tam, and JS-III species groups, which include Larix species. In terms of MOR value for Picea obovata, approximately $70 \%$ of total lumber fitted to SS and No. 1 grades in the S-P-F species group. In addition, the $f_{0.05}$ of the MOR in Picea obovata (11.7 MPa) was lower than the $F_{\mathrm{b}}$ of No. 3 grade $(12.6 \mathrm{MPa})$ for the S-P-F species group, suggesting that Picea obovata naturally grown in Mongolia does not belong to the S-P-F species group that includes many Picea species. On the other hand, the value was higher than the $F_{\mathrm{b}}$ in No. 3 grade in the $\mathrm{W}$ Cedar species group $(9.6 \mathrm{MPa})$. When the results obtained from Picea obovata were compared with those of the W Cedar species group, approximately $85 \%$ of lumber fitted to SS and No. 1 grades, and the $f_{0.05}$ exceeded No. 3 grade of the species group. Thus, Picea obovata lumber naturally grown in Mongolia should be regarded as lumber of the $\mathrm{W}$ Cedar species group rather than that of the S-P-F species group. However, further research is needed to obtain data on bending properties using a larger number of samples.

\section{Visual grading}

Table 4 shows the results of the visual grading of lumber in each species expressed as percentage of each grade. The percentage of lumber assigned into the SS grade were $91.8 \%, 82.1 \%, 35.8 \%$, and $32.4 \%$ in Pinus sylvestris, Pinus sibirica, Picea obovata, and L. sibirica, respectively. Among the four species, the lowest and the highest percentage of out of grade lumber were found in Pinus sylvestris (6.6\%) and in L. sibirica (29.7\%). Table 5 shows downgrading factors in the visual grading of lumber in each species. For lumber produced from Picea obovata, main downgrading factors from SS or SS + No. 1 grades to lower grades were knot $(37.3 \%)$ or twist $(25.4 \%)$. For $L$. sibirica lumber, wane (48.6\%) and twist (32.4\%) were the main downgrade factors from SS + No.1 grades. In Picea species, whorled branches occurred along the stems with short intervals [29]. This characteristic may be related to the large number of knots in Picea obovata used in the present study. In addition, lumber twist is induced by the presence of spiral grain in Picea and Larix species [20, 30, 31]. Thus, twist and wane observed in lumber from Picea obovata and $L$. sibirica are considered to be caused by the presence of spiral grain. Tumenjargal et al. [12] examined the visual grading for 2 by $4(38 \times 89 \mathrm{~mm})$ lumber of $L$. sibirica produced in Mongolia, and they reported that the wane, twist, and knot were the main factors for the downgrading of lumber. Our results obtained in $L$. 

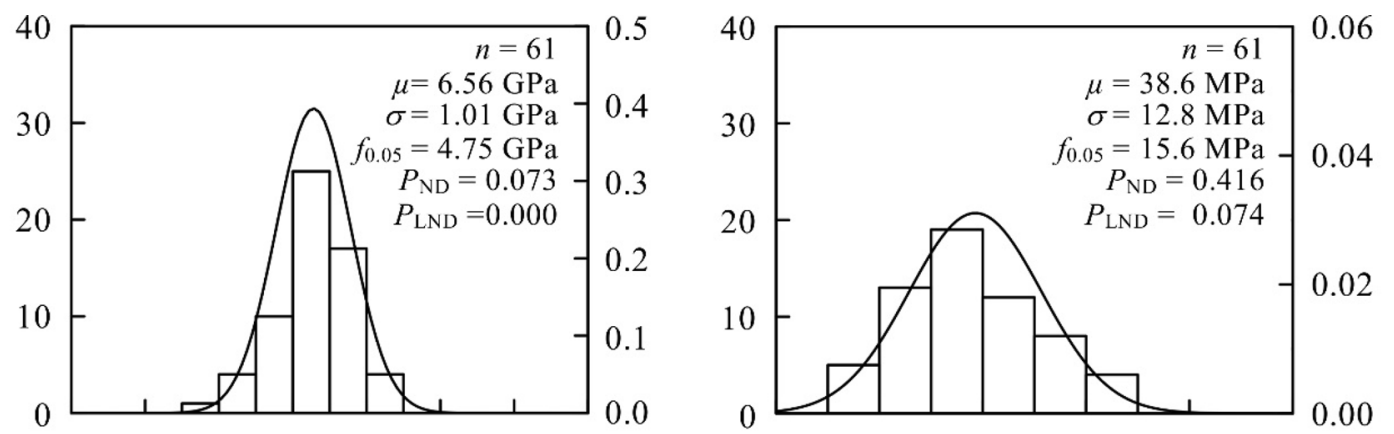

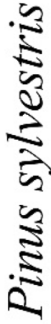
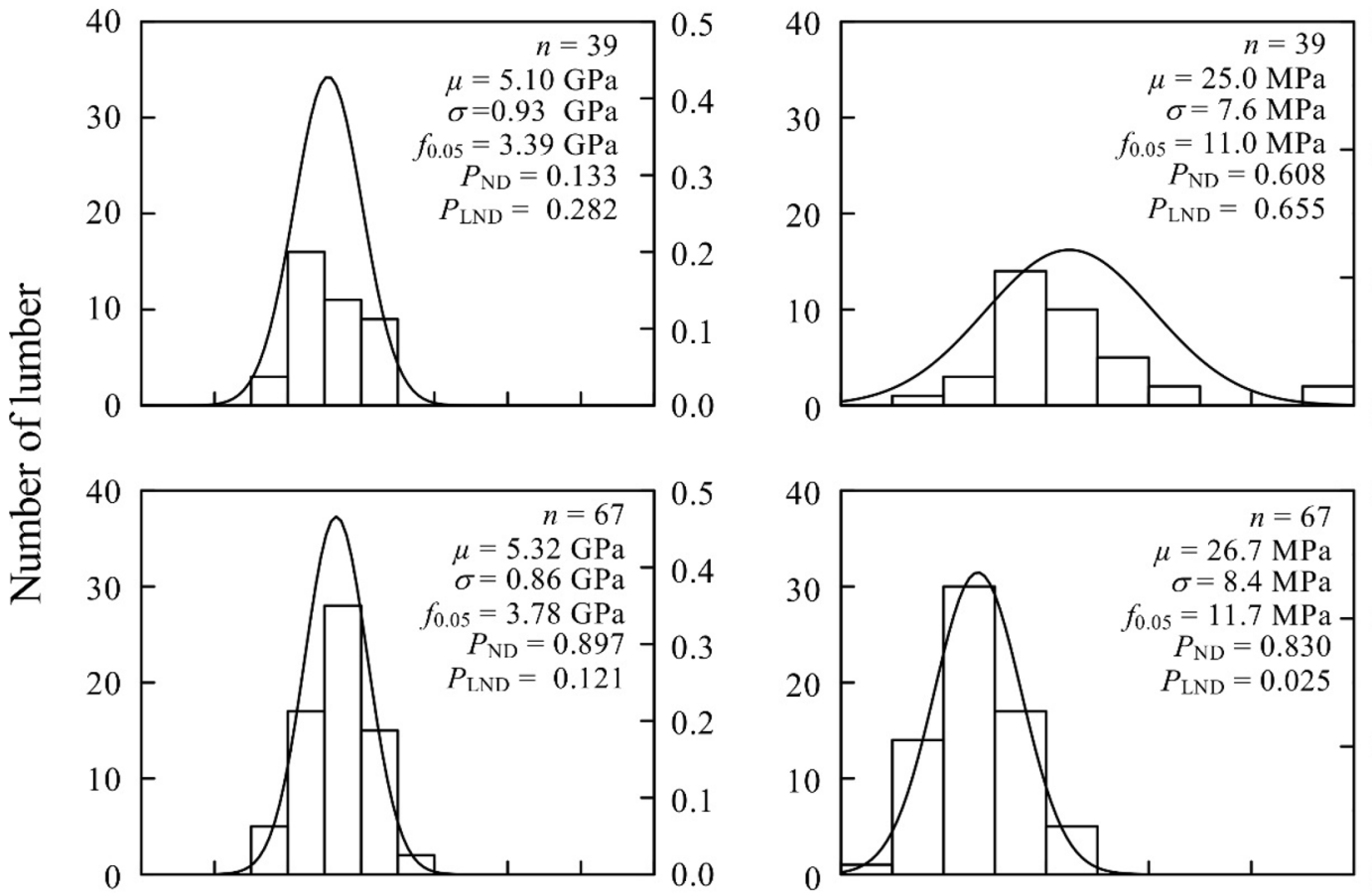

0.06

0.04

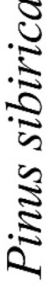

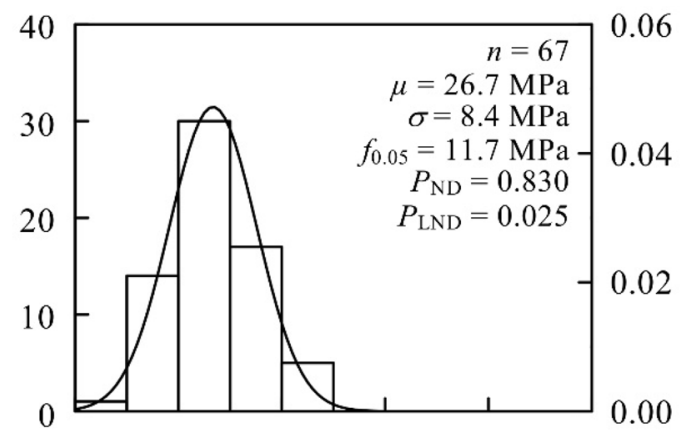

0
0
0
0
0
0
0
0
0
0
0
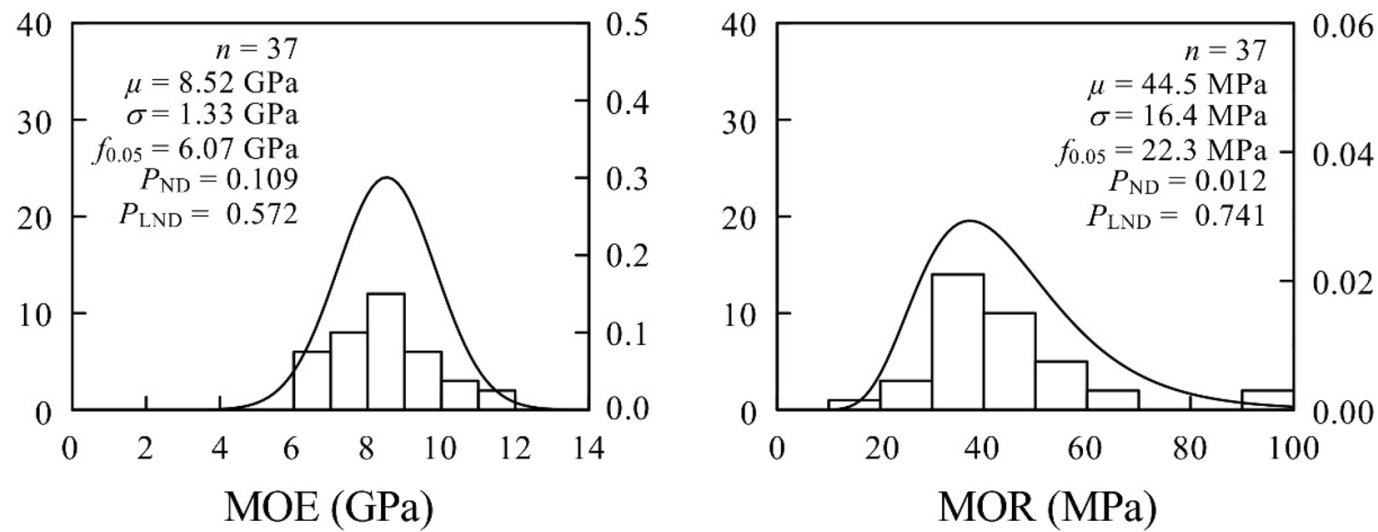

Fig. 2 Distribution of the MOE and MOR of lumber in each species. n, number of lumber; MOE and MOR, modulus of elasticity and modulus of rupture adjusted to the values at 15\% moisture content by the methods described in Japan Housing and Wood Technology Center [27]; $\mu$, mean value; $\sigma$, standard deviation; $f_{0.05}$, the $5 \%$ lower tolerance limit with a $75 \%$ confidence level; $P$, probability obtained by Shapiro-Wilk test as test of normality of normal distribution (ND) or logarithmic normal distribution (LND) 
Table 3 Characteristic value of the MOR $\left(F_{b}\right)$ and quantity of lumber of $F_{b}$ in each grade

\begin{tabular}{|c|c|c|c|c|c|c|}
\hline Property & Species group & SS & No. 1 & No. 2 & No. 3 & Out \\
\hline \multirow[t]{5}{*}{$F_{b}(\mathrm{MPa})$} & D. fir- $L$ & 36.0 & 24.6 & 21.6 & 12.6 & - \\
\hline & Hem-Tam & 29.4 & 18.0 & 13.8 & 8.4 & - \\
\hline & S-P-F & 30.0 & 22.2 & 21.6 & 12.6 & - \\
\hline & W Cedar & 23.4 & 16.8 & 16.2 & 9.6 & - \\
\hline & JS-III & 22.5 & 16.1 & 15.5 & 9.0 & - \\
\hline \multirow{7}{*}{$\begin{array}{l}\text { Quantity of lumber of } F_{b} \text { in each } \\
\text { grade (\%) }\end{array}$} & Pinus sylvestris vs. S-P-F & 70.5 & 21.3 & 0.0 & 8.2 & 0.0 \\
\hline & Pinus sibirica vs. W Cedar & 59.0 & 25.6 & 0.0 & 15.4 & 0.0 \\
\hline & Picea obovata vs. S-P-F & 32.8 & 35.8 & 1.5 & 25.4 & 4.5 \\
\hline & Picea obovata vs. W Cedar & 59.7 & 25.4 & 3.0 & 11.9 & 0.0 \\
\hline & L. sibirica vs. D. fir-L & 64.9 & 29.7 & 2.7 & 2.7 & 0.0 \\
\hline & L. sibirica vs. Hem-Tam & 89.2 & 2.7 & 8.1 & 0.0 & 0.0 \\
\hline & L. sibirica vs. JS-III & 97.3 & 2.7 & 0.0 & 0.0 & 0.0 \\
\hline
\end{tabular}

SS, select structural; Out, out of grade; $F_{b}$ value for each grade was specified in JAS for structural lumber and finger jointed structural lumber for wood frame construction [25]. -, no $F_{\mathrm{b}}$ values were listed in out of grade in JAS [25]. Quantity of lumber of $F_{\mathrm{b}}$ in each grade indicates percentage of quantity of lumber with MOR values exceeding the $F_{\mathrm{b}}$ in each grade for SS to No. 3 grade, and that below $F_{\mathrm{b}}$ of No.3 for out of grade

Table 4 Number of lumber and frequency percentage of each grading class of lumber in each species

\begin{tabular}{lcclc}
\hline Grade & Pinus sylvestris & Pinus sibirica & Picea obovata & L. sibirica \\
\hline SS & $56(91.8)$ & $32(82.1)$ & $24(35.8)$ & $12(32.4)$ \\
No.1 & $1(1.6)$ & $0(0.0)$ & $13(19.4)$ & $0(0.0)$ \\
No.2 & $0(0.0)$ & $2(5.1)$ & $20(29.9)$ & $10(27.0)$ \\
No.3 & $0(0.0)$ & $1(2.6)$ & $3(4.5)$ & $4(10.8)$ \\
Out & $4(6.6)$ & $4(10.3)$ & $7(10.4)$ & $11(29.7)$ \\
Total & $61(100.0)$ & $39(100.0)$ & $67(100.0)$ & $37(99.9)$ \\
\hline
\end{tabular}

SS, select structural; Out, out of grade. Values in parenthesis indicate frequency percentage of each grade (\%)

sibirica were similar to those reported by Tumenjargal et al. [12]. Based on the results, it was concluded that (1) Pinus sylvestris and Pinus sibirica trees could produce lumber with fewer knots, wane, and warp, and such lumber was mainly assigned into the SS grade; and (2) the presence of knot, wane, and twist should be considered for producing lumber with higher grade in Picea obovata and L. sibirica.

\section{Sawing pattern}

To examine the effects of sawing patterns (type I, II, and III, Fig. 1) on the bending properties of dimension lumber, mean values of MOE and MOR in each wood type were calculated. The results are shown in Table 6. In Pinus sylvestris and L. sibirica, the MOE and MOR of lumber in type III were significantly higher than those in types I and II. It has been reported that MOE and MOR values in 2 by 4 lumber consisting of mature wood were significantly higher than those consisting of juvenile wood in Southern pine (Pinus spp., [16, 23]), Pinus taeda
[11, 24], and L. sibirica [13]. In the present study, lumber classified into types I and II mainly contained juvenile wood, whereas lumber classified into type III included mature wood. Thus, the results obtained in Pinus sylvestris and L. sibirica were similar to those obtained in Pinus taeda and Larix species [11, 13, 24]. On the other hand, no significant differences were found in Pinus sibirica and Picea obovata lumber among the three sawing patterns, suggesting that wood properties of juvenile wood were similar to those in mature wood for Pinus sibirica and Picea obovata. However, further detailed research is needed for clarifying wood properties in juvenile wood and mature wood in these two species. The obtained results indicated that sawing pattern should be considered for producing lumber with higher mechanical properties in Pinus sylvestris and L. sibirica. However, for Pinus sibirica and Picea obovata, lumber with similar mechanical properties can be obtained regardless of sawing pattern.

\section{Relationships among lumber properties}

Table 7 shows correlation coefficients between annual ring width and measured properties of lumber produced from the four species. Significant negative correlations with air-dry density were found in type III lumber and total lumber (without classification of lumber types) in Pinus sylvestris and Picea obovata, whereas a positive correlation was found in type III lumber in $L$. sibirica. For mechanical properties, negative correlations were found in types I (except for MOR) and II and in total lumber in Pinus sylvestris and for total lumber in Picea obovata (except for MOR). In the present study, lumber classified into type I and II might consist of juvenile 
Table 5 Downgrading factors in the visual grading of lumber in each species

\begin{tabular}{|c|c|c|c|c|c|}
\hline \multirow[t]{2}{*}{ Factor } & \multirow[t]{2}{*}{ Grade } & \multicolumn{4}{|c|}{ Quantity of downgraded lumber in each species (\%) } \\
\hline & & Pinus sylvestris $(n=61)$ & Pinus sibirica $(n=39)$ & Picea obovata $(n=67)$ & $\begin{array}{l}\text { L. sibirica } \\
(n=37)\end{array}$ \\
\hline \multirow[t]{4}{*}{ Knot } & SS & 1.6 & 2.6 & 37.3 & 10.8 \\
\hline & No. 1 & & 2.6 & 7.5 & 5.4 \\
\hline & No. 2 & & & & \\
\hline & No. 3 & & & & \\
\hline \multirow[t]{2}{*}{ ARW } & SS-No. 2 & & & & \\
\hline & No. 3 & & & & \\
\hline \multirow[t]{3}{*}{ Wane } & SS-No. 1 & 6.6 & 7.7 & 13.4 & 48.6 \\
\hline & No. 2 & 6.6 & 5.1 & 6.0 & 27.0 \\
\hline & No. 3 & 6.6 & 5.1 & 4.5 & 13.5 \\
\hline \multirow[t]{4}{*}{ Fiber orientation } & SS & & & 1.5 & \\
\hline & No. 1 & & & 1.5 & \\
\hline & No. 2 & & & 1.5 & \\
\hline & No. 3 & & & & \\
\hline \multirow[t]{4}{*}{ Crack } & SS & & & 1.5 & 2.7 \\
\hline & No. 1 & & & 1.5 & 2.7 \\
\hline & No. 2 & & & & 2.7 \\
\hline & No. 3 & & & & \\
\hline \multirow[t]{2}{*}{ Crook } & SS-No. 1 & & 5.1 & 4.5 & 8.1 \\
\hline & No. 2-3 & & 5.1 & 4.5 & 8.1 \\
\hline \multirow[t]{3}{*}{ Bow } & SS-No. 1 & & 2.6 & & \\
\hline & No. 2 & & 2.6 & & \\
\hline & No. 3 & & & & \\
\hline \multirow[t]{3}{*}{ Twist } & SS-No. 1 & & & 25.4 & 32.4 \\
\hline & No. 2 & & & 9.0 & 18.9 \\
\hline & No. 3 & & & 3.0 & 13.5 \\
\hline
\end{tabular}

$n$, number of lumber; ARW, annual ring width; SS, select structural. The value was calculated from the ratio of the lumber downgraded to total lumber number in each species. When the threshold values of the JAS for structural lumber and finger jointed structural lumber for wood frame construction [25] are the same in several visual grading classes in a factor, the classes were combined

Table 6 Mean values of lumber properties in each wood type in four species

\begin{tabular}{|c|c|c|c|c|c|c|}
\hline \multirow[t]{2}{*}{ Species } & \multirow[t]{2}{*}{ Wood type } & \multirow[t]{2}{*}{$n$} & \multicolumn{2}{|c|}{ MOE (GPa) } & \multicolumn{2}{|c|}{ MOR (MPa) } \\
\hline & & & Mean & SD & Mean & SD \\
\hline \multirow[t]{3}{*}{ Pinus sylvestris } & I & 19 & $6.11^{\mathrm{a}}$ & 1.12 & $31.0^{\mathrm{a}}$ & 9.8 \\
\hline & $\|$ & 16 & $6.27^{\mathrm{a}}$ & 0.97 & $33.3^{\mathrm{a}}$ & 10.6 \\
\hline & III & 26 & $7.08^{b}$ & 0.71 & $47.3^{b}$ & 10.9 \\
\hline \multirow[t]{3}{*}{ Pinus sibirica } & । & 11 & $5.01^{\mathrm{a}}$ & 1.13 & $24.8^{a}$ & 7.5 \\
\hline & $\|$ & 10 & $5.03^{a}$ & 0.59 & $23.9^{\mathrm{a}}$ & 4.8 \\
\hline & III & 18 & $5.20^{\mathrm{a}}$ & 0.99 & $25.8^{\mathrm{a}}$ & 9.1 \\
\hline \multirow[t]{3}{*}{ Picea obovata } & । & 13 & $5.10^{\mathrm{a}}$ & 0.77 & $26.7^{\mathrm{a}}$ & 8.5 \\
\hline & $\|$ & 18 & $5.47^{\mathrm{a}}$ & 0.92 & $27.8^{\mathrm{a}}$ & 7.1 \\
\hline & III & 36 & $5.33^{\mathrm{a}}$ & 0.86 & $26.1^{\mathrm{a}}$ & 9.2 \\
\hline \multirow[t]{3}{*}{ L. sibirica } & । & 13 & $8.06^{\mathrm{a}}$ & 1.11 & $41.0^{\mathrm{a}}$ & 10.8 \\
\hline & $\|$ & 16 & $8.20^{\mathrm{a}}$ & 1.14 & $39.6^{\mathrm{a}}$ & 12.1 \\
\hline & III & 8 & $9.89^{b}$ & 1.17 & $60.1^{b}$ & 22.7 \\
\hline
\end{tabular}

$n$, number of lumber; MOE and MOR, modulus of elasticity and modulus of rupture adjusted to the values at $15 \%$ moisture content by the methods described in Japan Housing and Wood Technology Center [27]; SD, standard deviation; I, lumber including pith at almost-center position in cross section; II, lumber obtained near the pith (sometimes including pith on the surface area of the lumber); III, lumber obtained from outer part of the logs (without pith). The same letters followed by mean values in each species indicate no significant differences at the $5 \%$ level according to the Tukey-HSD test 
Table 7 Correlation coefficients between annual ring width and lumber properties in each wood type

\begin{tabular}{|c|c|c|c|c|c|c|}
\hline Species & Wood type & $n$ & $A D$ & DMOE & MOE & MOR \\
\hline \multirow[t]{4}{*}{ Pinus sylvestris } & I & 19 & $\begin{array}{l}-0.267 \\
(0.269)\end{array}$ & $\begin{array}{l}-0.573 \\
(0.010)\end{array}$ & $\begin{array}{l}-0.563 \\
(0.012)\end{array}$ & $\begin{array}{l}-0.426 \\
(0.069)\end{array}$ \\
\hline & $\|$ & 16 & $\begin{array}{l}-0.293 \\
(0.271)\end{array}$ & $\begin{array}{l}-0.838 \\
(0.000)\end{array}$ & $\begin{array}{l}-0.710 \\
(0.002)\end{array}$ & $\begin{array}{l}-0.552 \\
(0.027)\end{array}$ \\
\hline & III & 26 & $\begin{array}{l}-0.484 \\
(0.012)\end{array}$ & $\begin{array}{l}-0.346 \\
(0.084)\end{array}$ & $\begin{array}{l}-0.258 \\
(0.203)\end{array}$ & $\begin{array}{l}-0.017 \\
(0.935)\end{array}$ \\
\hline & Total & 61 & $\begin{array}{l}-0.399 \\
(0.001)\end{array}$ & $\begin{array}{l}-0.552 \\
(0.000)\end{array}$ & $\begin{array}{l}-0.505 \\
(0.000)\end{array}$ & $\begin{array}{l}-0.339 \\
(0.008)\end{array}$ \\
\hline \multirow[t]{4}{*}{ Pinus sibirica } & I & 11 & $\begin{array}{l}-0.407 \\
(0.214)\end{array}$ & $\begin{array}{l}-0.129 \\
(0.705)\end{array}$ & $\begin{array}{l}-0.201 \\
(0.554)\end{array}$ & $\begin{array}{l}-0.249 \\
(0.460)\end{array}$ \\
\hline & $\|$ & 10 & $\begin{array}{l}0.147 \\
(0.685)\end{array}$ & $\begin{array}{l}0.438 \\
(0.205)\end{array}$ & $\begin{array}{l}0.312 \\
(0.380)\end{array}$ & $\begin{array}{l}-0.170 \\
(0.639)\end{array}$ \\
\hline & III & 18 & $\begin{array}{l}-0.214 \\
(0.393)\end{array}$ & $\begin{array}{l}-0.155 \\
(0.540)\end{array}$ & $\begin{array}{l}-0.190 \\
(0.451)\end{array}$ & $\begin{array}{l}-0.113 \\
(0.654)\end{array}$ \\
\hline & Total & 39 & $\begin{array}{l}-0.170 \\
(0.302)\end{array}$ & $\begin{array}{l}-0.039 \\
(0.816)\end{array}$ & $\begin{array}{l}-0.107 \\
(0.516)\end{array}$ & $\begin{array}{l}-0.157 \\
(0.338)\end{array}$ \\
\hline \multirow[t]{4}{*}{ Picea obovata } & I & 13 & $\begin{array}{l}-0.198 \\
(0.516)\end{array}$ & $\begin{array}{l}-0.348 \\
(0.244)\end{array}$ & $\begin{array}{l}-0.198 \\
(0.516)\end{array}$ & $\begin{array}{l}-0.397 \\
(0.179)\end{array}$ \\
\hline & $\|$ & 18 & $\begin{array}{l}-0.300 \\
(0.212)\end{array}$ & $\begin{array}{l}-0.119 \\
(0.640)\end{array}$ & $\begin{array}{l}-0.228 \\
(0.362)\end{array}$ & $\begin{array}{l}-0.106 \\
(0.676)\end{array}$ \\
\hline & III & 36 & $\begin{array}{l}-0.668 \\
(0.000)\end{array}$ & $\begin{array}{l}-0.281 \\
(0.097)\end{array}$ & $\begin{array}{l}-0.285 \\
(0.092)\end{array}$ & $\begin{array}{l}-0.169 \\
(0.325)\end{array}$ \\
\hline & Total & 67 & $\begin{array}{l}-0.360 \\
(0.003)\end{array}$ & $\begin{array}{l}-0.294 \\
(0.016)\end{array}$ & $\begin{array}{l}-0.276 \\
(0.024)\end{array}$ & $\begin{array}{l}-0.204 \\
(0.098)\end{array}$ \\
\hline \multirow[t]{4}{*}{ L. sibirica } & I & 13 & $\begin{array}{l}0.072 \\
(0.816)\end{array}$ & $\begin{array}{l}0.383 \\
(0.196)\end{array}$ & $\begin{array}{l}0.204 \\
(0.503)\end{array}$ & $\begin{array}{l}0.169 \\
(0.581)\end{array}$ \\
\hline & $\|$ & 16 & $\begin{array}{l}0.076 \\
(0.779)\end{array}$ & $\begin{array}{l}0.163 \\
(0.545)\end{array}$ & $\begin{array}{l}0.258 \\
(0.336)\end{array}$ & $\begin{array}{l}0.074 \\
(0.786)\end{array}$ \\
\hline & III & 8 & $\begin{array}{l}0.950 \\
(0.000)\end{array}$ & $\begin{array}{l}0.536 \\
(0.171)\end{array}$ & $\begin{array}{l}0.682 \\
(0.063)\end{array}$ & $\begin{array}{l}0.006 \\
(0.989)\end{array}$ \\
\hline & Total & 37 & $\begin{array}{l}0.280 \\
(0.094)\end{array}$ & $\begin{array}{l}0.262 \\
(0.118)\end{array}$ & $\begin{array}{l}0.297 \\
(0.074)\end{array}$ & $\begin{array}{l}0.086 \\
(0.612)\end{array}$ \\
\hline
\end{tabular}

$n$, number of lumber; AD, air-dry density at testing; DMOE, dynamic Young's modulus; MOE and MOR, modulus of elasticity and modulus of rupture adjusted to the values at $15 \%$ moisture content by the methods described in Japan Housing and Wood Technology Center [27]; I, lumber including pith at almost-center position in cross section; II, lumber obtained near the pith (sometimes including pith on the surface area of the lumber); III, lumber obtained from outer part of the logs (without pith). Values in parentheses followed by correlation coefficients are $p$-values obtained by a test of no correlation

wood, and type III lumber mainly had mature wood. Juvenile wood is characterized by larger ring width and lower wood density and mechanical properties $[11,13$, 32, 33]. Thus, differences in the relationships between annual ring width and lumber properties among the four species might be affected by wood type, that is, juvenile wood versus mature wood. Particularly, in Pinus sylvestris, the mechanical properties of lumber in types I and II were negatively affected by radial growth, whereas these lumber properties from type III were not affected by radial growth. The results suggested that mechanical properties of this species are not directly correlated with radial growth rate, but were closely related with the presence of juvenile wood.

Air-dry density was significantly correlated with dynamic Young's modulus and/or MOE in Pinus sylvestris, L. sibirica, and Picea obovata, whereas it was not significantly correlated with MOR in all species (Fig. 3).

(See figure on next page.)

Fig. 3 Correlation coefficients among lumber properties in the four softwood species. n, number of lumber; AD, air-dry density at testing; DMOE, dynamic Young's modulus; MOE and MOR, modulus of elasticity and modulus of rupture adjusted to the values at 15\% moisture content by the methods described in Japan Housing and Wood Technology Center [27]; $r$, correlation coefficients. Values in parentheses followed by correlation coefficients are $p$-values obtained by a test of no correlation 

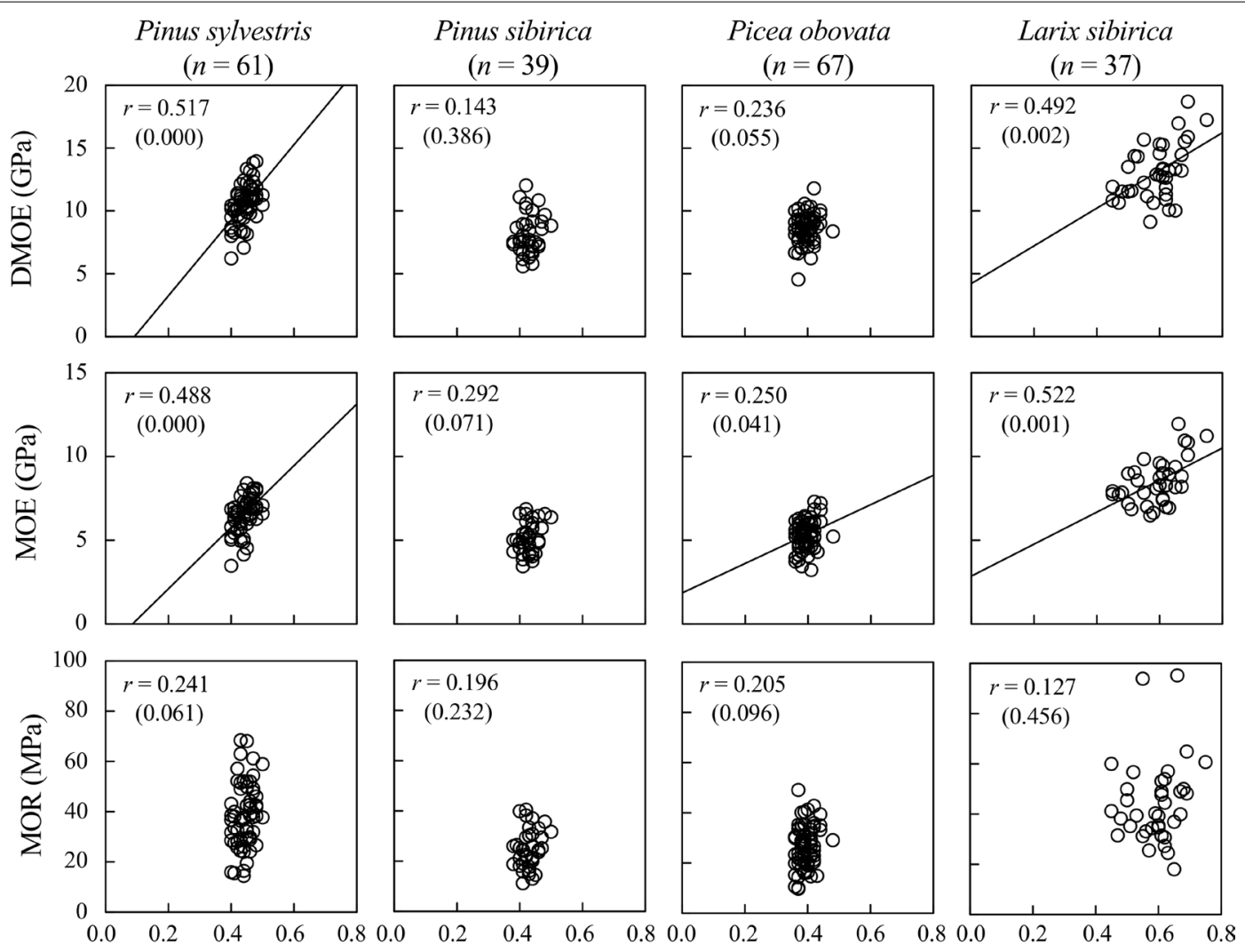

$\mathrm{AD}\left(\mathrm{g} / \mathrm{cm}^{3}\right)$
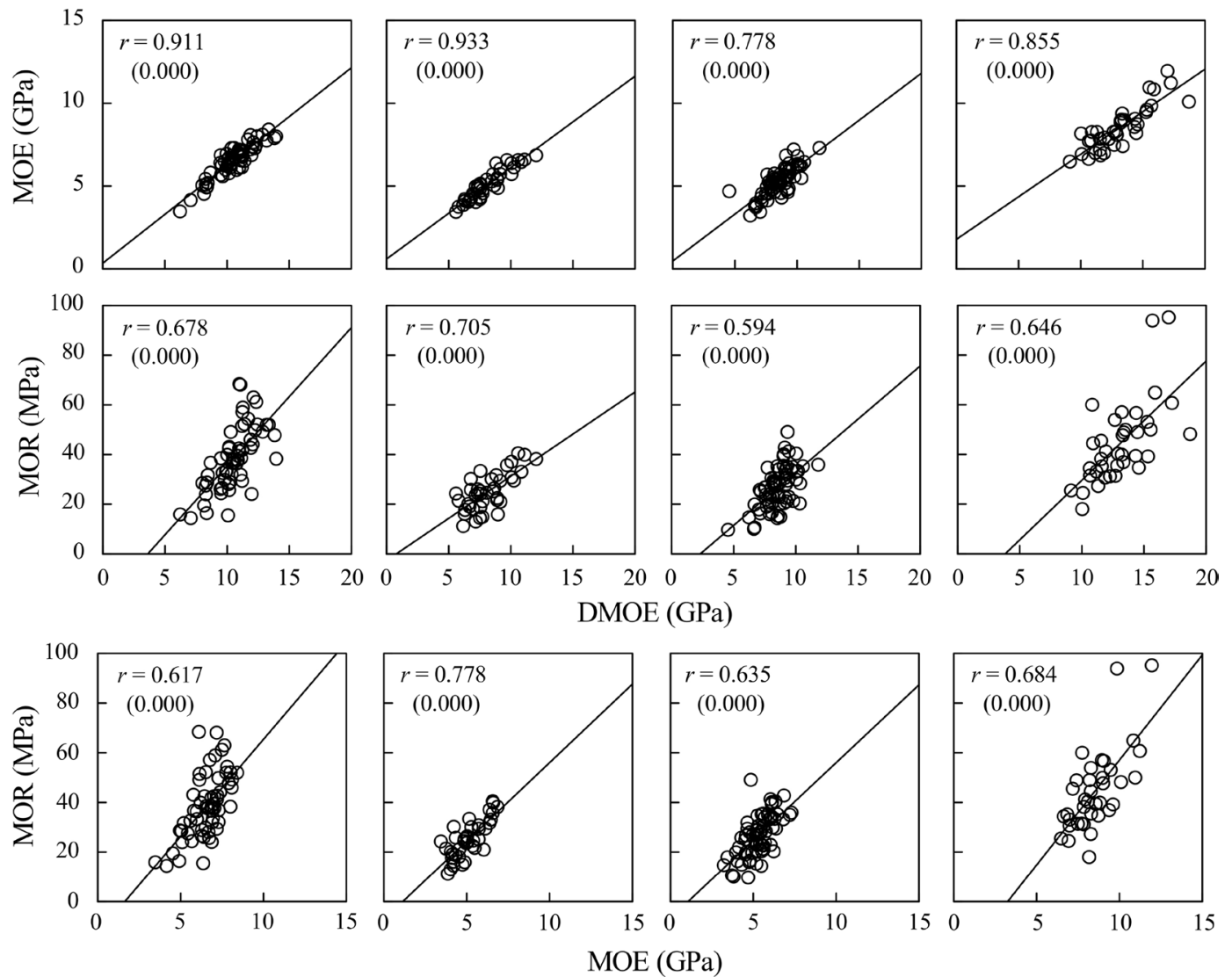
These obtained results indicated that MOR may be affected by other properties, such as microfibril angle or the number and size of knots in the lumber. Similar lower correlation coefficients between wood density and MOR were found in full-size lumber of Picea glauca (Moench) Voss [7], Pinus radiata D. Don [18], and L. sibirica [13].

For all species, dynamic Young's modulus demonstrated significant positive correlations with the MOE and MOR of lumber (Fig. 3). Similar significant positive correlations between dynamic Young's modulus and MOE or MOR were found in 2 by 4 lumber of Cryptomeria japonica D. Don, Taiwania cryptomerioides Hayata, and Pseudotsuga menziesii (Mirb.) Franco [34], Southern pine [34, 35], and L. sibirica [12].

Significant positive correlations between MOE and MOR in full-size lumber have also been reported in Picea glauca [36], L. kaempferi [6], Pinus taeda [24], and L. sibirica [13]. In the present study, MOE was significantly positively correlated with the MOR of lumber in all species (Fig. 3), indicating that MOR can be predicted nondestructively by $\mathrm{MOE}$ in lumber produced from the four Mongolian softwood species.

Results suggest that when annual ring width is used as visual grading criteria for estimating air-dry density and mechanical properties of lumber, the relationships between annual ring width and lumber properties differ among species and wood types. Compared to the airdry density of lumber, nondestructive testing, such as dynamic Young's modulus, is effective for determining the static bending properties in all four species.

\section{Conclusions}

In the present study, dimension lumber qualities were investigated for four common Mongolian softwood species, Pinus sylvestris, Pinus sibirica, Picea obovata, and $L$. sibirica. The $f_{0.05}$ values for MOE and MOR were $4.75 \mathrm{GPa}$ and $15.6 \mathrm{MPa}, 3.39 \mathrm{GPa}$ and $11.0 \mathrm{MPa}$, 3.78 $\mathrm{GPa}$ and $11.7 \mathrm{MPa}$, and $6.07 \mathrm{GPa}$ and $22.3 \mathrm{MPa}$ for Pinus sylvestris, Pinus sibirica, Picea obovata, and L. sibirica, respectively. The lumber qualities of the four species were characterized as follows: (1) lumber from Pinus sylvestris had low warp with moderate bending properties; (2) lumber from Pinus sibirica and Picea obovata had lower bending properties with lower dimension stability; and (3) lumber from $L$. sibirica had higher bending properties with larger twist. In visual grading, a higher percentage of SS grade lumber was obtained from Pinus sylvestris and Pinus sibirica trees, whereas the highest percentage of lumber in $L$. sibirica was assigned to No. 3 or out of grade. Lumber classified into type III in Pinus sylvestris and L. sibirica displayed higher bending properties compared with that in lumber types I and II, suggesting that sawing patterns in relation to the presence of juvenile wood was important for producing lumber with high mechanical properties in these two species. Significant correlations between dynamic Young's modulus, MOE, and MOR were found in all species, indicating that MOE and MOR could be estimated nondestructively using dynamic Young's modulus. Based on the results, it can be concluded that dimension lumber for structural use can be produced from these four common Mongolian softwoods, although lumber in each species demonstrated different lumber quality characteristics.

\section{Abbreviations \\ $f_{0.05}: 5 \%$ Lower tolerance limit with a $75 \%$ confidence level; $F_{b}$ : Characteristic values of MOR; MOE: Modulus of elasticity; MOR: Modulus of rupture; SS: Select structural; S-P-F: Spruce-Pine-Fir.}

\section{Acknowledgements}

The authors would like to thank Ms. Miyu Nakata, School of Agriculture, Utsunomiya University for her assistance in measuring lumber properties.

\section{Authors' contributions}

MS contributed to experiments, data analysis, and writing the manuscript. FI designed this study and contributed to experiments, data analysis, and writing the manuscript. BT, YT, and IN contributed to experiments and data analysis. $\mathrm{BB}$ and GC contributed to experiments. JO and SY contributed to discussion on the obtained results. All authors read and approved the final manuscript.

\section{Funding}

A part of this research was financially supported by the M-JEED program of the Ministry of Education, Culture, Science, and Sports, Mongolia.

\section{Availability of data and materials \\ Not applicable.}

\section{Ethics approval and consent to participate}

The wood samples used in the present study were collected with the observance of Mongolian laws.

Consent for publication

Not applicable.

\section{Competing interests}

The authors declare that they have no competing interests.

\section{Author details \\ ${ }^{1}$ School of Agriculture, Utsunomiya University, Utsunomiya 321-8505, Japan. ${ }^{2}$ United Graduate School of Agricultural Science, Tokyo University of Agricul- ture and Technology, Fuchu, Tokyo 183-8509, Japan. ${ }^{3}$ Training and Research Institute of Forestry and Wood Industry, Mongolian University of Science and Technology, Ulaanbaatar 5172, Mongolia. ${ }^{4}$ School of Industrial Technol- ogy, Mongolian University of Science and Technology, Ulaanbaatar 14191, Mongolia.}

Received: 22 May 2020 Accepted: 23 September 2020 Published online: 09 October 2020

\section{References}

1. Ministry of Environment, Green Development and Tourism (2016) Forest resource in Mongolia. Forest Study and Development Center, Ulaanbaatar (In Mongolia) 
2. FAO (2018) Yearbook of forest products. https://www.fao.org/3/cb051 3m/CB0513M.pdf. Accessed on 30 Aug 2019

3. Kretschmann DE, Bendtsen BA (1992) Ultimate tensile stress and modulus of elasticity of fast-grown plantation loblolly pine lumber. Wood Fiber Sci 24:189-203

4. Kliger IR, Perstorper M, Johansson G, Pellicane PJ (1995) Quality of timber products from Norway spruce. Part 3. Influence of spatial position and growth characteristics on bending stiffness and strength. Wood Sci Technol 29:397-410

5. Larsson D, Ohlsson S, Perstorper M, Brundin J (1998) Mechanical properties of sawn timber from Norway spruce. Holz Roh Werkst 56:331-338

6. Nagao H, Washino K, Kato H, Tanaka T (2003) Estimation of timber strength based on the distribution of MOE in the stem: application to Japanese larch. Mokuzai Gakkaishi 49:59-67 (In Japanese with English summary)

7. Beaulieu J, Zhang SY, Yu Q, Rainville A (2006) Comparison between genetic and environmental influences on lumber bending properties in young white spruce. Wood Fiber Sci 38:553-564

8. Duchesne I (2006) Effect of rotation age on lumber grade yield, bending strength and stiffness in jack pine (Pinus banksiana Lamb.) natural stands. Wood Fiber Sci 38:84-94

9. Ishiguri F, Matsui R, lizuka K, Yokota S, Yoshizawa N (2008) Prediction of the mechanical properties of lumber by stress-wave velocity and Pilodyn penetration of 36-year-old Japanese larch trees. Holz Roh Werkst 66:275-280

10. Shiiba A, Aratake S, Fujimoto Y, Oda H, Matsumoto A (2012) Mechanical performance of sugi (Cryptomeria japonica) wooden frame-construction lumber and evaluation of stress grading. Mokuzai Gakkaishi 58:90-99 (In Japanese with English summary)

11. Tanabe J, Ishiguri F, Nakayama M, Ohshima J, lizuka K, Yokota S (2016) Properties of juvenile and mature wood and their effects on the bending properties of lumber in Pinus taeda growing in Tochigi, Japan. For Prod J 66:428-432

12. Tumenjargal $B$, Ishiguri F, Aiso-Sanada $H$, Takahashi Y, Nezu I, Baasan B, Chultem G, Ohshima J, Yokota S (2019) Geographical variations of lumber quality of Larix sibirica naturally grown in five different provenances of Mongolia. J Wood Sci 65:43

13. Tumenjargal B, Ishiguri F, Takahashi Y, Nezu I, Baasan B, Chultem G, AisoSanada H, Ohshima J, Yokota S (2020) Bending properties of dimension lumber produced from Siberian larch (Larix sibirica) in Mongolia. J Wood Sci 66:17

14. Zhang SY, Chauret G, Ren HQ Desjardins R (2002) Impact of initial spacing on plantation black spruce lumber grade yield, bending properties, and MSR yield. Wood Fiber Sci 34:460-475

15. Tong QJ, Fleming RL, Tanguay F, Zhang SY (2009) Wood and lumber properties from unthinned and precommercially thinned black spruce plantations. Wood Fiber Sci 41:168-179

16. Dahlen J, Jones PD, Seale RD, Shmulsky R (2014) Bending strength and stiffness of wide dimension southern pine No. 2 lumber. Eur J Wood Prod 72:759-768

17. lijima Y (2007) Standardization of testing and evaluation method for fullsize structural timber strength in Japan. Mokuzai Gakkaishi 53:63-71 (In Japanese with English summary)

18. Bier $\mathrm{H}$ (1985) Bending properties of structural timber from a 28-year-old stand of New Zealand Pinus radiata. New Zealand J For Sci 15:233-250

19. Erikson RG, Gorman TM, Green DW, Graham D (2000) Mechanical grading of lumber sawn from small-diameter lodgepole pine, ponderosa pine, and grand fir trees from Northern Idaho. For Prod J 50(7/8):59-65
20. Johansson M, Kliger R (2002) Influence of material characteristics on warp in Norway spruce studs. Wood Fiber Sci 34:325-336

21. Lemieux H, Beaudoin M, Zhang SY, Grondin F (2002) Improving structural lumber quality in a sample of Picea mariana logs sawn according to the knots. Wood Fiber Sci 34:266-275

22. Zhong Y, Ren HQ, Jiang ZH (2016) Experimental and statistical evaluation of the size effect on the bending strength of dimension lumber of Northeast China larch. Materials 9:89

23. Dahlen J, Jones PD, Seale RD, Shmulsky R (2014) Sorting lumber by pith and its effect on stiffness and strength in southern pine No. $22 \times 4$ lumber. Wood Fiber Sci 46:186-194

24. Butler MA, Dahlen J, Daniels RF, Eberhardt TL, Antony F (2016) Bending strength and stiffness of loblolly pine lumber from intensively managed stands located on the Georgia Lower Coastal Plain. Eur J Wood Prod 74:91-100

25. MAFF (2020) https://www.maff.go.jp/j/jas/jas_kikaku/attach/pdf/kikak u_itiran2-374.pdf. Accessed on 14 Aug 2020 (In Japanese)

26. Sobue N (1986) Measurement of Young's modulus by the transient longitudinal vibration of wooden beams using a fast Fourier transformation spectrum analyzer. Mokuzai Gakkaishi 32:744-747

27. Japan Housing and Wood Technology Center (2011) Kouzouyoumokuzai no kyoudoshiken manual (Manual of strength testing for structural lumber). www.howtec.or.jp/files/libs/1828/201712121507021978.pdf. Accessed 6 Oct 2019 (In Japanese)

28. R Core Team (2018) R: A language and environment for statistical computing. R Foundation for Statistical Computing, Vienna, Austria. https:// www.R-project.org/. Accessed 1 Feb 2019

29. Tanabe J, Makino K, Ishiguri F, Yamashita K, Katsuki T, Kubojima Y, Ohno H, Kameyama Y, Andoh Y, lizuka K, Yokota S, Yoshizawa N (2013) Growth and stress-wave velocity of trees of Picea koyamae growing in plantation and its wood quality of 2 by 4 lumber. Wood industry 68:198-203 (In Japanese with English summary)

30. Kano T, Nakagawa S, Saito H, Oda S (1964) On the quality of Larch timber (Larix leptolepis Gordon) Report 1. Influence of some conditions about the characteristics in trees, logs and squares. Bull Govern For Exp Station 162:1-48 (In Japanese with English summary)

31. Piispanen R, Heikkinen J, Valkonen S (2020) Deformations of boards from uneven-aged Norway spruce stands. Eur J Wood Wood Prod 78:533-544

32. Bendtsen BA, Senft J (1986) Mechanical and anatomical properties in individual growth rings of plantation-grown eastern cottonwood and loblolly pine. Wood Fiber Sci 18:23-38

33. Zhu J, Nakano T, Hirakawa Y (2000) Effects of radial growth rate on selected indices for juvenile and mature wood of the Japanese larch. J Wood Sci 46:417-422

34. Wang SY, Chen JH, Tsai MJ, Lin CJ, Yang TH (2008) Grading of softwood lumber using non-destructive techniques. J Mat Proc Technol 208:149-158

35. França FJN, Seale RD, Shmulsky R, França TSFA (2019) Assessing southern pine $2 \times 4$ and $2 \times 6$ lumber quality: longitudinal and transverse vibration. Wood Fiber Sci 51:1-14

36. Zhou H, Smith I (1991) Factors influencing bending properties of White spruce lumber. Wood Fiber Sci 23:483-500

\section{Publisher's Note}

Springer Nature remains neutral with regard to jurisdictional claims in published maps and institutional affiliations. 